\title{
Malignant Epithelial Cells with Cytoplasmic Vacuoles or Flocculent Cytoplasmic Inclusions Containing Wispy Eosinophilic Material Present
}

National Cancer Institute

\section{Source}

National Cancer Institute. Malignant Epithelial Cells with Cytoplasmic Vacuoles or

Flocculent Cytoplasmic Inclusions Containing Wispy Eosinophilic Material Present. NCI

Thesaurus. Code C157714.

A morphologic finding indicating the presence of malignant epithelial cells with cytoplasmic vacuoles or flocculent cytoplasmic inclusions containing wispy eosinophilic material giving a bubbly appearance. 